\title{
THE TELL-TALE "HEART": DETERMINING “FAIR" USE OF UNPUBLISHED TEXTS
}

\author{
Karen Burke LeFevre*
}

I

\section{INTRODUCTION}

\author{
The Tell-Tale "Heart" 1
}

Ms. D-,$^{2}$ a college professor and a scholar, has had the great good luck to discover the untouched papers of a deceased, hitherto unknown writer and professor (born in 1870, died in 1920) named Athena Rhetoric. Among Athena Rhetoric's papers, which were donated many years ago to D-'s university library, D- has found Athena's lecture notes and correspondence, her students' class notes, an unpublished book manuscript, diaries, and other

Copyright $\odot 1992$ by Karen Burke LeFevre

- Associate Professor of Rhetoric and Composition, Rensselaer Polytechnic Institute, Troy, New York.

An earlier version of this article was presented at the Society for Critical Exchange conference on Intellectual Property and the Construction of Authorship (April 1991), organized by Peter Jaszi and Martha Woodmansee. I am grateful to a number of people for helpful conversations about the subject of this article, especially Carol Colatrella, Diane Conley, Kenneth Connor, David Lange, Jim LeFevre, David Porush, Patricia Search, and Timothy Seldes.

1. The purpose of this fictional tale is to illustrate some of the problems posed by current copyright law. My "tale" of biographer D-'s experience with Athena and Meta Rhetoric is hypothetical and fictitious. The characters, institutions, places, and incidents are imagined or are used fictitiously. Any resemblance to actual persons living or dead should not be inferred. However, references to existing law and court cases explicitly named herein are factual to the best of my nonlawyer's knowledge, as are the footnoted references to other works. The theoretical, ethical, and practical concerns reflected in this fiction are, I feel, quite realistic. Finally, although I have studied the legal issues involved in this area, I am not a lawyer; therefore, I cannot and do not make any warranties about any information in this article or any uses to which it is put. My goal is not to advise, but rather to show some of the uncertainties and questions that current copyright laws and interpretations may cause for writers who are not lawyers. Readers needing legal advice should consult a lawyer about the particulars of their own situations. Organizations that may help with referrals include The Authors Guild, 330 West 42nd Street, NY, NY 10036, and Volunteer Lawyers for the Arts, 1 East 53 Street, 6th Floor, NY, NY 10022.

The title of this tale and many allusions in it clearly stand on the shoulders of Edgar Allan Poe. The title recalls Edgar Allan Poe's The Tell-Tale Heart, in Edward H. Davidson, ed, Selected Writings of Edgar Allan Poe 194-99 (Houghton Mifflin, 1956). Poe seems a fitting author to use for this topic, not only because some of his tales deal with the attempted rational analysis of mysterious and gloomy circumstances, but also because he wrote essays that made him, according to Alexander Lindey, the "first man of letters in America to give serious thought to the subject of originality and derivation ..." Alexander Lindey, Plagiarism and Originality 94 (Harper \& Brothers, 1952). These essays, circa 1844-1850, are collected in Edgar Allan Poe, Marginalia (U Press Virginia, 1981).

2. Ms. D-, the fictitious biographer in my article, recalls Poe's character, Minister D-, in Edgar Allan Poe, The Purloined Letler, in Davidson, Selected Writings at 208-25 (cited in note 1). Poe's Minister D- is described as a thief who has purloined a letter from a woman; the question is not who took the document, but how to get it back without letting others know about it. 
primary sources. Athena's books are heavily annotated; the margins of her copy of Aristotle's Rhetoric, for instance, are filled with her incisive handwritten commentary.

Information about Athena Rhetoric's family is sparse. Athena apparently was happily married. Her husband died long ago, but the Rhetorics' only child, a daughter named Meta, could conceivably still be alive. Meta became a circus performer in the 1930s, moved to the Midwest, and has not been heard from since. No one knows whether Meta Rhetoric is dead or alive or has children or heirs.

As D- studies the papers, she becomes fascinated with her discovery. Athena Rhetoric was a feminist and an influential educator at a small Southern college. Her comprehensive theories anticipated much of contemporary rhetoric. It seems fitting that her name was Athena, after the versatile goddess of wisdom and the state who at the same time celebrated the arts of domesticity and the hearth. D- wants to show what it was like for Athena to be a woman, a teacher, a mother, a wife, a colleague, and a rhetorician in her time. In modern parlance, Athena "had it all."

To make Athena's contributions known, D- plans to write a book that will interpret Athena's writings, showing their significance in both past and present. At the same time, D- will show how Athena lived and worked, making this account vivid through the details she has been carefully recording from Athena's unpublished diaries and letters. D- can show that Athena wore a black hat during the week, but a festive blue on Sunday. Athena would curse the president of her college one day, but bake him a loaf of raisin bread the next. She coined new, and not necessarily proper, words to satirize the popular rhetoric textbooks of her time. She opposed teaching spelling to young children because it would hamper their use of language. "Let words spill from their mouths and pour from their pens," she advised.

For months, then years, D- continues reading, carefully turning yellowed pages that threaten to crumble between her gloved fingers. Some of the libraries she visits allow researchers to make a photocopy or other reproduction of unpublished material. Others interpret copyright law differently and will neither loan copies through interlibrary loan nor permit photocopying of unpublished material without permission of the copyright owner, whose identity in this instance is uncertain. In such cases, D- must copy materials by hand, a laborious process that introduces errors and requires long, expensive stays in distant cities. ${ }^{3}$

Over time, D- fills stacks of note cards. She teaches in summer school to earn money so she can afford a few trips. She visits Athena's home town on

3. See Michael Les Benedict, Historians and the Continuing Controversy over Fair Use of Unpublished Manuscript Materials, 4 Am Historical Rev 859-81 (1986). In this thorough discussion (published after Harper $\mathcal{E}$ Row, but before Salinger and New Era, all of which are discussed shortly), the author notes that applying a restrictive view of copyright law to photocopying of unpublished materials by individual scholars or libraries could seriously affect researchers by increasing their time, effort, and expenses: "It would suggest exchanging in scholarly research the technology of the twentieth century for that of the twelfth." Id at 871 . 
the Maine coast to see the streets she walked. She travels to Hartford, Atlanta, and Charleston, searching for sources. Alone in these cities, Dtypically puts in eight hours at a library and then goes to a movie she has seen before, ending the day by watching the late local news on a bolted-down motel TV. Athena has become the fixed point in D-'s world. If D- finds a book on rhetoric published in 1890, she wonders if Athena read it. If Dlearns that a debate was held on Athena's campus, she searches obsessively for clues to see if Athena was there.

At last, having completed much of her research, $\mathrm{D}-$ sits with hands suspended over her computer keyboard, ready to write. However, over the years while she has been working, $D$ - has heard rumors about a legal controversy involving a biography of the reclusive author J. D. Salinger. Dlooks up several newspaper articles about the lawsuit, which in turn lead her to other recent court decisions limiting the use of unpublished works. Deciding that she ought to find out what the pit is like before the pendulum strikes, D- gets copies of the opinions along with some self-help law books, hoping they will give some guidance about how to proceed. She finds that copyright law is more complex than she had ever imagined. Still, she tries to figure out the basics in order to get on with her project.

D- discovers that, according to copyright law, a writer may generally report facts, ideas, and information obtained from unpublished sources, since these are not protected by copyright. ${ }^{4}$ However, copyright law does protect what courts have called the original author's "expressive content," "expressive material," or "expression of facts."'5 Such writings may not be "copied" or "used"-quoted or closely paraphrased-without the copyright owner's permission except when the "use" by a second author (such as D-) is judged a fair use under copyright law.

Due to the nature of D-'s work, a great deal depends on how much use is fair use when the use involves unpublished papers written at any time, from centuries ago up to yesterday. Any use beyond this amount would require the permission of the copyright holder, who might be the author, the author's executors or heirs, or some other person or institution. After reading the recent cases, D- discovers that fair use of unpublished works has been severely limited. The limitations apply whether the copyright owners are living or dead, and whether the unpublished materials are obtained privately or are available in public places such as libraries. Thus, even though the materials might be in D-'s university library, and even though the library gives her permission to publish from them, that is not necessarily enough if she wishes to use them more extensively than fair use would allow.

4. "As with all works of authorship, the copyright owner secures protection only for the expressive content of the work, not the ideas or facts contained therein ...., a distinction fundamental to copyright law and of special significance in determining whether infringement has occurred in a work of biography or other account of historical or contemporary events." Salinger $v$ Random House, Inc., 811 F2d 90, 95 (2d Cir 1987)(citations omitted). However, some ideas or facts might be protected under laws other than copyright, for example, privacy or patent laws.

5. Id at 96,100 . 
A key case on this point is Salinger $v$. Random House, ${ }^{6}$ which involved biographer Ian Hamilton's attempt to quote and paraphrase brief selections from unpublished letters written by J. D. Salinger, author of Catcher in the Rye. Salinger, who seemed extremely uninterested in being the subject of a biography, sued for copyright infringement. In 1987, the Court of Appeals for the Second Circuit found that Random House (and Hamilton) had exceeded fair use guidelines under which an author may quote and paraphrase limited amounts of another author's expressive material without permission. ${ }^{7}$

The 1985 Supreme Court ruling in Harper $\mathcal{G}$ Row Publishers, Inc. v. Nation Enterprises ${ }^{8}$ first developed the presumption, applied in Salinger, against fair use of virtually any unpublished copyrighted expression. In Harper $\xi$ Row, The Nation magazine had obtained an unpublished manuscript of a forthcoming book by President Gerald Ford and published a review quoting about 300-400 of Ford's unpublished words prior to another first serial publication already licensed by Ford's publisher, Harper \& Row. The subsequent Salinger decision stated that if a writer uses "more than minimal amounts of (unpublished) expressive content, he deserves to be enjoined." 9 It seemed that a subject of a biography who suspected that a forthcoming biography might contain an undefined "more than minimal" amount of the subject's unpublished copyrighted material could seek, and expect to receive, an injunction blocking publication.

At first, it appeared that an injunction might be virtually automatic, but the author of the Salinger opinion, Second Circuit judge Jon O. Newman, later suggested that injunctions are not automatic, but are discretionary. ${ }^{10}$ Courts could also consider other factors (such as the public interest) before issuing them. In a later case, New Era Publications International v. Henry Holt, Co., ${ }^{11}$ the Second Circuit permitted Holt to distribute Russell Miller's biography of the late L. Ron Hubbard (founder of Scientology and author of Dianetics ${ }^{12}$ ) because of a technicality. ${ }^{13}$ However, the opinion expressed the view that the biographer's use of even brief quotations and close paraphrases of Hubbard's unpublished works was not a fair use.

D- takes the law very seriously. For years she left tags attached to the pillows in her bedroom because they said "DO NOT REMOVE UNDER PENALTY OF LAW." She has no legal training, however, so she struggles

6. 811 F2d 90 (2d Cir 1987).

7. Id at 96,100 .

8. 471 US 539 (1985).

9. Salinger, 811 F2d at 96.

10. New Era Publications Intl ApS v Henry Holt and Co., 884 F2d 659, 663-64 (2d Cir 1989) (Newman dissenting from the denial of rehearing en banc), denying rehearing of $873 \mathrm{~F} 2 \mathrm{~d} 576$ (2d Cir 1989) ("New Era $I ")$.

11. 873 F2d 576 (2d Cir 1989) ("New Era I").

12. L. Ron Hubbard, Dianetics (Am Saint Hill Org., 1972) (distributed by the Church of Scientology).

13. "The prejudice suffered by Holt as the result of New Era's unreasonable and inexcusable delay in bringing the action invokes the bar of laches." New Era I, 873 F2d at 584. 
while attempting to translate the opinions she has read into practical steps to take with her project. One option that comes to mind is to try to avoid the fair use question altogether by getting permission from Athena's daughter, Meta, who may be the copyright owner. D- decides to look for Meta. She searches telephone directories of major cities and runs notices in newspapers but receives no response. Circus records from the 1930s are hard to obtain and, unfortunately, the recent court opinions give D-no guidance on how long or how hard she should look.

D- lies awake nights wondering what will happen if she does locate Meta. It could be wonderful. Meta might be excited by D-'s work; she might offer memories and insights. But $\mathrm{D}-$ cannot help imagining less attractive possibilities:

1. Meta may be one of many who think that "rhetoric" is bad, that it is what George Bush accused Saddam Hussein of using. She might not want $\mathrm{D}$ - to tell the world that her mother was a rhetorician.

2. What if Meta refuses to permit D- to quote from her mother's materials? Or wants D- to pay a substantial amount for the privilege? (At this point, D- has already invested many years' effort and many dollars in this work.)

3. Meta might want to approve D-'s manuscript as a condition for granting permission.

4. Meta could decide to write a book about Athena herself. Perhaps she would feel that D-'s book might be undesirable competition.

5. The libraries containing papers $\mathrm{D}-$ needs could be asked to restrict access.

6. Finally, if D-cannot find Meta Rhetoric, but Meta turns up after D-'s book is published, could Meta complain, or could she sue?

Nor are Athena and Meta the only concerns; D - has other questions:

1. She would like to quote excerpts from the unpublished letters by students, faculty, and administrators who wrote to Athena. Where does D- search for them or their heirs to get permission?

2. Who owns the copyright to the notes Athena's students took of her oral lectures? To an essay that appears to have been a collaboration between Athena and several other faculty and students? To an uncredited photograph of Athena that was in her papers?

In light of these questions and possible problems, D- briefly considers abandoning her work. However, she decides that her best course would be to limit her use of unpublished works to fair use, if she can figure out how to do so.

The copyright laws require that courts consider at least four factors in determining whether a quotation or close paraphrase of another's 
unpublished work without permission is a fair use. ${ }^{14}$ Courts look to: (1) the purpose of use; (2) the nature of the work used; (3) how much, both in quantity and quality, a work uses an author's "creative expression"; and (4) whether the use will affect the value of the unpublished work. D- studies these factors one by one. On the first factor, $\mathrm{D}$ - figures she should be in good shape. Several district and circuit court decisions have found that biographies that contribute to criticism, scholarship, or research generally fit fair use guidelines. ${ }^{15}$

However, a look at the other three factors shows a darker shade of gray. In both Salinger and New Era I, the Second Circuit ruled that these three factors went to the advantage of the source, and thus against the biographer. On the second factor, the court's position about use of unpublished works was starkly stated in New Era I: "[w]here use is made of materials of an 'unpublished nature,' the second fair use factor has yet to be applied in favor of an infringer ...."16 In Salinger, the Second Circuit opinion stated that works that are unpublished "normally enjoy complete protection against copying any protected expression."'17

In a more recent case, Wright $v$. Warmer Books, ${ }^{18}$ the Second Circuit Court of Appeals continued to take the position that factor two favors the plaintiff when unpublished works are used. In this case, biographer Margaret Walker and her publisher, Warner Books, were sued by Ellen Wright, widow of the late Richard Wright, the author of Native Son and Black Boy. Ellen Wright complained that Walker's biography of Richard Wright had wrongfully made use of some of his published and unpublished works. Both the district and appellate court decisions ultimately favored the biographer/defendant. However, on the second factor itself, regarding the unpublished nature of the copyrighted works, the appellate court disgreed with the district court's view that factor two favored the biographer. Based on previous rulings in Harper $\mathfrak{E}$ Row, Salinger, and New Era I, the appeals court once again found that factor two favored the plaintiff: "[o]ur precedents . . . leave little room for discussion of this factor once it has been determined that the copyrighted work is unpublished." 19

D- fears that she might also face difficulty on the fourth factor, which has generally been considered the most important. The Supreme Court in Harper $\mathcal{E}^{2}$ Row and the Second Circuit Court of Appeals in Salinger and New Era I ruled that the secondary use of the unpublished work would likely decrease its market value for the copyright owner, so this factor weighed against the

14. 17 USC \& 107 (1976).

15. "Our cases establish that biographies in general, and critical biographies in particular, fit "comfortably within' these statutory categories 'of uses illustrative of uses that can be fair.' " New Era Publications International ApS v Carol Publishing Group, 904 F2d 152, 156 (2d Cir 1990)("New Era II"), citing Salinger, 811 F2d at 96 and New Era I, 873 F2d at 583.

16. New Era I, 873 F2d at 583.

17. Salinger, 811 F2d at 97 (emphasis added).

18. 748 F Supp 105 (SDNY 1990), aff'd, 953 F2d 731 (2d Cir 1991). Margaret Walker's biography of Wright is Richard Wright Daemonic Genius (Warner Books, 1988).

19. Wright, 953 F2d at 737. 
biographer. In Wright $v$. Warner Books, however, the court of appeals agreed with the district court that the fourth factor favored the biographer-an encouraging turn of events for $\mathrm{D}$ - . She notes, however, that the Second Circuit based this finding on a very small amount of unpublished material: "seven instances in which the biography takes Wright's expression."20 Given the court's current stance, D- worries that if she quotes or closely paraphrases more than a "minimal" amount of Athena's unpublished material, she may be at risk. And so much will be lost in substance and readability if she has to write a biography of Athena that makes such restricted use of primary, unpublished sources.

Finally, D- looks at factor three, which may have room for interpretation. Here, the court would consider how much, in terms of both quantity and quality, D- uses of Athena's "creative expression." Although this factor weighed against the biographer in the appeals court rulings in both Salinger and New Era I, it went in favor of the biographer in Wright, which gives Dsome slight hope. ${ }^{21}$

This third factor raises some key questions. First, can D- clearly distinguish which elements are "ideas" or "facts" (which she may use) from those that are Athena's "expression" (which she usually may not)? For example, D- believes that she can legally report the "fact" that Athena got soaked by the rain on April 28 of a certain year if Athena recorded that event in her journal. ${ }^{22}$ However, the use of Athena's statement that the rhetorics of her time demonstrate "the logic of a crazy quilt" is less clear. That statement is Athena's opinion, but for D-'s purposes, it could also be considered a fact that Athena held that opinion and a fact that Athena said it. ${ }^{23}$

20. Id at $\mathbf{7 4 0 .}$.

21. In Wright, Judge John Walker found the biographer's use to be insubstantial, and therefore a fair use, $748 \mathrm{~F}$ Supp at 105 , and the court of appeals agreed that the biographer's "sparing use" of creative expression was fair use. 953 F2d at 739 .

22. Whether that statement of "fact" is accurate or not is another story and is not always easily determined, even about things that seem fairly uncontroversial. For example, witness the confusion about facts concerning Poe, who has been the subject of much scholarship and numerous biographies for more than a century. "Speculations abound," according to a recent compilation that claims to contain what are allegedly "the verifiable facts" about Poe. "One commentator suggests that Poe was impotent while another tries to prove that he impregnated someone else's wife." Dwight Thomas \& David K. Jackson, The Poe Log: A Documentary Life of Edgar Allan Poe, 1809-1849, ix-x (G. K. Hall, 1987). According to John C. Miller, some "facts" that have been disputed over time include Poe's place of birth (Baltimore or Boston?), his year of birth (1809, 1811, or 1813?), and the identity of the woman to whom his poem "Annabel Lee" is addressed (four women have claimed that distinction). John C. Miller, Poe's Biographers Brawl, Am History Illustrated 7, 11, 29 (Nov 1976).

23. Although facts are often ambiguous in biography, Mary Sarah Bilder notes that the law seems to operate as if facts objectively exist and as if judges can make distinctions between fact and expression. "Intuitive judicial division of fact and expression bars 'fact' as a fluid concept. The presumption that a quotation is 'expression' bars the use of quotation as fact." Mary Sarah Bilder, The Shrinking Back: The Law of Biography, 43 Stan L Rev 299, 349 (1991). This places severe constraints on the biographer's ability to work.

To remedy this situation in part, Bilder proposes that what she terms "fact use" be permitted. "In short, fact use suggests that biographers' quotations of unpublished expression should be classified as 'fair' under the fact/expression part of a copyright analysis and thus permitted." Id at 356. She points to comments in several district court opinions that resemble this rationale, but observes that an appellate court has not yet recognized it. Id. 
A similar distinction that the law requires is the separation of a source's ideas (which may be used by a biographer) and the source's expression of those ideas (which generally may not). Understandably, the courts find that this "idea/expression dichotomy" is sometimes difficult to discern. D-'s task is further complicated because she does not always understand how judges arrive at such distinctions. For instance, in Wright, the appellate court deemed the biographer's paraphrases of some journal entries to be "borderline expression."24 How is D- to know where that border lies? And in Salinger, the court noted that biographer Hamilton erred in copying from a number of Salinger's letters, “including several highly expressive insights about writing and literary criticism."25 What is meant by "highly expressive insights"? "Insights" might be roughly the same as "ideas," which, even if highly original or unique in substance, are supposedly not protected by copyright and thus could presumably be used. But a "highly expressive insight" seems to be something different, something that intermingles expression and idea. Is it something else that D- cannot use? Her book grows slimmer by the minute.

Another issue concerns how much use of Athena's "creative expression" is too much to be deemed fair use. D- discovers that, unfortunately, " $[t]$ he rule of thumb is that there is no rule of thumb."26 Furthermore, the court considers more than just the amount of use. In Harper $\mathcal{E}$ Row, some 300-400 unpublished words of a source were considered an acceptable "minimal" number when used in an article of 2,250 words. ${ }^{27}$ (Words from the original source made up about 13 percent of the user's article.) However, infringement occurred anyway, the court said, because those $300+$ words were the "heart" of the source. ${ }^{28}$ In another case, original unpublished material made up only about 1 percent of an author's book, but again infringement occurred because the unpublished letters were "prominently featured" in the work that used them. ${ }^{29}$ In Salinger, the Second Circuit examined each of forty-four letters by Salinger to determine how much of each one was quoted or closely paraphrased in Hamilton's biography. ${ }^{30}$

After surveying several cases, D- lists some sample questions she might have to answer to determine fair use:

24. Wright, 953 F2d at 736 .

25. Salinger, 811 F2d at 99.

26. Irwin Karp, Authors League Symposium on Copyright: January 27, 1982, 61 1, 645 (reprinted by permission from J Copyright Bulletin, August 1982).

27. Harper $\mathrm{G}^{\circ}$ Row, 471 US at 566.

28. Id at 567 .

29. Meeropol v Nizer, 560 F2d 1061, 1071 (2d Cir 1977).

30. The Second Circuit found that Salinger's unpublished letters were quoted or paraphrased on $40 \%$ of the 192 pages in Hamilton's biography. Examining 59 passages from Hamilton's biography, the court found a "very substantial appropriation" of material drawn from 44 of Salinger's unpublished letters. Protected material from "at least one-third of 17 letters and at least $10 \%$ of 42 letters" was copied (quoted or closely paraphrased) by Hamilton. Salinger, 81 1 F2d at 98 99. 
1. How many words are in each separate unpublished document written by Athena? (And which words should D- count: Dates? Salutations? Signatures? Titles? Clichés?)

2. How many of those words does D- quote or closely paraphrase? In other words, how much of Athena's unpublished corpus does Duse?

3. What is the total number of words in D-'s book manuscript? How many of these words are quotations or close paraphrases of Athena's words? Also, how many passages and how many pages in D-'s book manuscript contain quotations or close paraphrases from Athena?

4. Are Athena's words prominently displayed in D-'s book?

Already D- sees potential problems in answering these questions because of her research procedures:

1. Throughout her years of research, D- did not count Athena's words in hundreds of documents. She does not know the total number of words in each separate document she has quoted.

2. D- does not know the total number of words in Athena's entire unpublished corpus, and determining that at this juncture is impossible.

3. D- cannot afford to travel to all the libraries again to count words and identify the "heart" of each document.

4. Furthermore, D- does not have photocopies of many of the libraries' unpublished material. In fact, there seems to be a Catch-22 at work. Some libraries, unsure about how to follow the vague fair use guidelines for making photocopies, will not provide a researcher with the copies that might enable the researcher to avoid violating those vague fair use guidelines.

This need to count words troubles D-. It brings back unwelcome memories of counting the words in her themes for freshman composition. Moreover, she cannot be sure about what is a "safe" number of words to use. D- decides she needs legal advice because even a minor, accidental miscalculation could have a devastating effect. No wonder the 1976 revision of the Copyright Act has been called the "full employment act" for lawyers. 31 Now D- must go about locating a good copyright lawyer, which could be an expensive proposition. Perhaps President Ford's publisher could afford to take a dispute over some 300 words all the way to the Supreme Court, but a college professor is not able to do this.

$\mathrm{D}$ - finds that the counting and weighing in the case of Athena Rhetoric is not over as she turns from quantity to quality. Courts may consider whether $\mathrm{D}$-'s use is substantial in a qualitative sense-that is, whether D- takes

31. Henry P. Tseng, New Copyright USA 206 (Amco International, 1979). 
Athena's protected material or "expressive content" by relying too closely on Athena's original patterns, or interpretations, or emphasis of points. ${ }^{32}$ They also look for the "tell-tale heart," which is, D- discovers, not always easy to identify.

In Harper $\mathcal{E}$ Row v. Nation Enterprises, The Nation magazine took from Gerald Ford, the court said, " 'the heart' of a 'soon-to-be published' work" and, in doing so, caused a first serial publication agreement between Ford's publisher and Time magazine "to be aborted." 33 As a consequence, Ford's publisher, Harper \& Row, lost the $\$ 12,500$ it would have received from Time's planned publication of Ford's excerpt if The Nation had not rushed it into print first.

D- considers the way in which the opinion uses terms like "heart" and "aborted." Does an unpublished work have a fetus-like status? Does harm to its "heart" abort a viable text? She recalls a sixties' novel by Richard Brautigan called The Abortion: An Historical Romance 1966.34 Brautigan described a fictional library to which authors take their unpublished works, in which they are perpetually protected and perpetually unread. Authors never see these manuscripts again, nor does anyone else: "Nobody ever checks them out and nobody ever comes here to read them."35 From there they are taken for storage to caves in California by Foster, an adoptive parent. ${ }^{36}$ This fictional library serves as a sealed environment transporting manuscripts that never reach readers: it is an "airplane of books, flying through the pages of eternity." 37 Is this to be the fate of Athena's unpublished works? To be shut up in cartons on library shelves?

Not if D-can help it. But she knows she had better figure out just what this "heart" is. The opinions often conclude that the "heart" of a copyrighted work was or was not taken without elaborating on what factors went into that decision. The courts seems to use a "you know it when you see it" test. The Harper $\mathcal{G}$ Row Supreme Court opinion quotes an editor who viewed the Ford chapters used by The Nation as "the most interesting and moving parts of the entire manuscript," and the court notes that The Nation wrongfully used "the most powerful passages" of these Ford chapters. ${ }^{38}$ These seem to constitute the "heart" in this case.

The "heart" might also refer to more than words quoted. Ian Hamilton said, "It wasn't just a matter of not stealing Salinger's exact words. Each of

32. Salinger, $811 \mathrm{~F} 2 \mathrm{~d}$ at 98 . "What is protected is the manner of expression, the author's analysis or interpretation of events, the way he structures his material and marshals facts, his choice of words and the emphasis he gives to particular developments." Wainwright Securities, Inc. $v$ Wall Street Transcript Corp., 558 F2d 91, 95-96 (2d Cir 1977).

33. Harper $\mathfrak{G}$ Row, 471 US at 564-65, quoting the lower court's opinion, 557 F Supp 1067, 1072 (SDNY 1983).

34. Published by Simon and Schuster in $\mathbf{1 9 7 0 .}$

35. Id at 20.

36. Id at 75

37. Id at 92. Brautigan died in 1984. In 1990, The Brautigan Library opened in Burlington, Vermont. Calling itself "A Very Public Library," it accepts unpublished literature only, which may be read by visitors on the premises. Part of its aim is to encourage writing that might not fit the commercial marketplace.

38. Harper E Row, 471 US at 566. 
his letters was, it seemed, a living thing and had a heart that could also be stolen." 39 According to Hamilton's description of the deposition process of the lawsuit, Salinger himself was shown each of his own letters that Hamilton had used and Salinger "was asked to identify its 'expressive heart' and to say how much of this he thought I had stolen. What was the 'main purpose' of each letter? Which was its 'most important' section?"40

Judging from the court opinions D- has read, she figures that the "heart" of a book may be whatever is most interesting, moving, powerful, important, or significant. The "central portion" is another possible candidate."1 Furthermore, the court may look for the "heart" in two places: in Athena's works and in the book D- is writing. Thou shalt not take thy subject's unpublished, copyrighted heart. And thou shalt not take what is less than thy subject's heart, but make it the heart of thy biography. ${ }^{42}$

This area is so complicated that even the courts disagree. For example, in Salinger, Judge Pierre Leval of the district court concluded that the passages the biographer used from Salinger's copyrighted material "are not the heart of Salinger's letters, nor of Hamilton's book." 43 However, while not claiming that Salinger's "heart" had been taken, the appellate court disagreed with Leval's overall evaluation of this factor. It felt that Hamilton's quotations and paraphrases of Salinger's unpublished letters were significant in quantity and quality. These letters provided an "important ingredient" for the biography that "to a large extent . . . make the book worth reading." 44

The phrase "make the book worth reading" confuses D-. Worth reading for whom? Is "heart"-or whatever else one calls the qualitative factors, whether of style or substance-something that is an inherent feature of the text? Or could it vary for different readers in different times and places? Should we ask the author, when available, to determine the "heart" of his or her own works, as seems to have been part of the procedure in the Salinger case? Or is that judgment up to a potential buyer such as the editor of Time, as was mentioned in Harper $\mathcal{E}$ Row? Or should that decision be left to the biographer? To the specialist reader? To the judge?

Often in copyright matters, the audience is assumed to be the average or ordinary reader. How should we characterize that audience in the case of unpublished works that have existed for some time, such as those of Athena

39. Ian Hamilton, In Search of J.D. Salinger 199 (Random House, 1988).

40. Id at 201.

41. Wright, 748 F Supp at 112.

42. In Wright, the Second Circuit states that "[t]here is some confusion whether factor three also should be examined in relation to the allegedly infringing work." $953 \mathrm{~F} 2 \mathrm{~d}$ at 738 . That is, should the court consider how much (quantitatively and qualitatively) of an allegedly infringing biography is composed of protected passages from the plaintiff's copyrighted works? Not so, the Second Circuit says in Wright: "the language of section 107 does not direct us to examine factor three in relation to the infringing work." Id at 739. Still, the court goes ahead and examines this relationship in Wright anyway, explaining that it does so "because our precedents have applied this gloss to factor three, and because this perspective gives an added dimension to the fair use inquiry . . .." Id.

43. 650 F Supp 413, 423 (SDNY 1986).

44. Salinger, $811 \mathrm{~F} 2 \mathrm{~d}$ at $98-99$. 
Rhetoric? Is "heart" what the late nineteenth century reader might have judged most powerful, most interesting, or most important? What if that is different now?

Before D- leaves the qualitative issues, she finds one more "organic" metaphor to reckon with. Some of the opinions allow a biographer to quote small amounts of unpublished material if she uses it as evidence for a claim she makes, to buttress her argument about her subject. However,the biographer/historian should not (at least according to certain judges) use it to "enliven" her own text. This term is also left undefined, but it seems to suggest that one should not animate one's biography text with the subject's expression.

In Wright v. Warner Books, D- is relieved to find that the district court judged biographer Margaret Walker's use of Richard Wright's "previously published creative expression" to be lawful. Walker quoted this material to "demonstrate its creativity" and to "provide substance to her literary critique" rather than to "enliven her text." 45 Thus, the biographer had safely refrained from reporting the facts in "a poetic style that might remain beyond her reach, or for that matter the reach of any biographer."46 The opinion describes Richard Wright's writings favorably as his "creative expression" that is present in his "brilliant novels and autobiographical works"; however, Wright's biographer-or any biographer-is apparently not expected to attain such "poetic style." 47

Why, D- wonders, should one assume "poetic style" to be out of reach of all biographers? Margaret Walker is a case in point. She is the author not only of the biography of Wright, but also of the novel Jubilee and five books of poetry, one of which (For My People) won the Yale Series of Younger Poets Award. It appears that even when a court rules in the biographer's favor, there may still be a lingering suggestion that a biographer's art is inferior to that of his or her subject. ${ }^{48}$ Thus, the biographer must be wary of

45. 748 F Supp at 109 .

46. Id

47. Id at 112 .

48. Diane Conley provides an excellent analysis of "the courts' hierarchical thinking" in recent copyright cases regarding fair use of unpublished material. The courts perceive some authors of fiction and poetry, for example, to be "original geniuses whose works spring, Athena-like, fully formed from their creative brows, and others as scavengers who piece together works by appropriating the creative labors of the more talented." Diane Conley, Author, User, Scholar, Thief: Fair Use and Unpublished Works, 9 Cardozo Arts \& Enter LJ 15, 21 (1990). The creative work done by "scavengers" such as biographers and historians is valued less, Conley notes, and hence is "insufficiently tolerated" by the courts, and that translates into decisions weighing against them. Id at 23.

The issue of who is the original creator and who is the secondary "user" becomes more complex when one looks at the process of composition. For example, according to two of Richard Wright's biographers (one of them Margaret Walker, the defendant in Wright $v$. Warner Books), parts of Wright's well-known novel, Native Son, apparently drew from an attorney's brief from a Chicago murder trial that was going on while Wright was writing his novel and also from numerous newspaper clippings about the trial that Margaret Walker had sent to Wright. "He said he had enough [clippings] to spread all over his nine-by-twelve bedroom floor," Walker wrote. "He would ... read them over and over again and then take off from there in his own imagination." Margaret Walker, Richard Wright Daemonic Genius 123 (Warner Books, 1988). See also Michel Fabre, The World 
"enlivening": taking (illegally) the subject's words to "put life into" the biographer's (otherwise lifeless?) text.

Finally, D- decides to play lawyer and apply the principles about "heart" and "enlivening" and "creative expression" to just one unpublished letter. To Athena Rhetoric, the audience was extremely important: it was not simply something or someone you addressed. The audience (actual or imagined) could stimulate the writer's ideas, affect purposes, and influence tone. She summed it up in three words: "Audience is all." D- wants to quote "Audience is all." It appears in a brief letter of thirty words, so it is just 10 percent of that letter, but this might still be too much. Someone could also argue that this sentence contains the "heart" of Athena's theory of rhetoric. Perhaps it does, but that is why it is worth quoting. D- hopes to use the sentence because it also shows the reader Athena's style. However, she may be accused of stealing Athena's "creative expression" to "enliven" her own prose.

D- is thoroughly upset. There it is: the "heart" of Athena's entire rhetorical enterprise in one sentence of three words, five syllables, thirteen letters. "Villains!" D- shrieks to an imaginary court. "I admit the deed!" 49 She begs the court for mercy: "Take thy beak from out my heart, and take thy form from off my door," but this is to no avail; quoth the judges: "Nevermore." 50 So she erases Athena's line and tries to paraphrase "Audience is all":

One of Ms. Rhetoric's key sentences conveys her sense that the role of the audience is an encompassing factor in any rhetorical situation. Moreover, the clipped style of the sentence suggests her conciseness and economy. Her prose passage also gives a hint of her affection for alliteration.

If $\mathrm{D}$ - writes this stuff, she may hear Athena rising up in protest from across the bar, her "heart" resounding in the library walls but heard so far only by $\mathrm{D}$ - as she murders Athena's prose in the attempt to preserve rights for an unfound heir who may think that rhetoric is something bad that politicians use. Like the "purloined letter" in one of Poe's stories, Athena's letters are simultaneously displayed and hidden. Although they may be placed "full in the view of every visitor," 51 so much of what is valuable remains effectively concealed from so many who cannot pay a visit.

D- wonders if Athena might wish to have her work more widely circulated. It is possible that, like so many women of her time, Athena could not get her works published earlier. Now that she could have an audience, the

of Richard Wright 65-66 (U Press Mississippi, 1985), where Fabre documents Wright's use of materials obtained from others, such as letters, court records, and magazines. Wright is not alone in using such methods, but the point that fiction writers (not just their biographers) are "creative users" of previously existing works sometimes gets overlooked.

49. Edgar Allan Poe, The Tell-Tale Heart, in Davidson, ed, Selected Writings at 199 (cited in note 1).

50. Edgar Allan Poe, The Raven, in Davidson, ed, Selected Writings at 223 (cited in note 1).

51. Edgar Allan Poe, The Purloined Letter, in Davidson, ed, Selected Writings at 223 (cited in note 1). 
law makes publication difficult. An important question about women's history has been, as Dale Spender puts it: "How are women made to disappear?" 52 Perhaps copyright law is one part of the answer to that question. If a person may not speak without someone else's permission, history is not an open dialogue between past and present. Perhaps Athena would want her words to be part of the social stream of conversation that can continue, by way of writing, across centuries.

Furthermore, D-conjectures, even if we cannot know Athena's intention, or even if Athena did not want us to use her works, we still have a valid claim on her as a member of the human community. After all, like the rest of us, Athena created in part by "using": using a language others taught her; using the works of authors living and dead; using the people with whom she talked and worked. When does society get to know the form and substance of Athena Rhetoric? The voice of the public is muffled when the legal debate is framed as the property rights of subject versus biographer, of one author versus another.

Finally D-decides that she is tired of worrying and guessing. She will not go through the ordeal of writing two different versions of her book-one that quotes or closely paraphrases a small amount of unpublished material, and one that does not-and then waiting to see if a publisher will choose to publish one or the other (or neither). ${ }^{53}$ Even if a publisher is willing to take a risk by including some unpublished material, a lawsuit could result, which would be time-consuming and expensive. Furthermore, D- is facing other pressures. She has to publish something or she may lose a promotion, or even her job. She cannot wait more than a decade until December 31, 2002, when papers such as Athena's may perhaps enter the public domain. ${ }^{54}$

D- realizes that the dilemma about unpublished materials affects not only those who write about Gerald Ford, J. D. Salinger, L. Ron Hubbard, Richard Wright, and others of fame and notoriety. It also affects the teacher who hopes to learn (and teach) about the process of writing by comparing unpublished early drafts of writing (whether by students, speech writers, or literary "greats") with later, published versions. It affects the journalist who locates and records certain logs and memoranda that provide crucial "evidence" about a current social controversy, but who may be unable to

52. Dale Spender, Women of Ideas (And What Men Have Done to Them) 4 (Routledge \& Kegan, 1983).

53. A Senate report on proposed legislation concerning fair use of unpublished material states that "[s]ome authors have been forced to produce two copies of works in progress: one fully supported with direct quotation from source material, and one sharply curtailed, with all direct quotation deleted." Fair Use of Unpublished Works, S Rep No 102-141, 102d Cong, 2d Sess 4 (July 8, 1991).

54. Typically (with some exceptions) copyright now subsists for the life of the author plus 50 years, according to Section 302 of the 1976 Copyright Act. Under Section 303, however, the term of copyright for "works created but not published or copyrighted before January 1, 1978" shall not in any case expire before December 31, 2002. Since the works by the fictional Athena Rhetoric were created prior to her death in 1920, their current term of protection thus would not expire before December 31, 2002 (and not before December 31, 2027 if they should be published by December 31, 2002). 
quote such documents since they might be regarded as unpublished as far as copyright is concerned.

Furthermore, the legal dilemma may discourage work by scholars who attempt to recover the writings of women, of minorities, of so-called "ordinary" or "marginal" people whose works have remained unpublished because they were unfound, unread, unrecognized for their merits, or actively suppressed. It seems ironic and regrettable if, when such works are finally found, the laws that purport to protect them as property keep them hidden instead.

However, D- cannot afford the luxury of regret. It is time to bail out by turning to something else. She will write about theory, which costs just the fare to the library, uses published books, and has fewer legal risks. Reluctantly, D- packs away her notes about Athena Rhetoric and pins on the bulletin board in her library carrel a passage from Poe's 1845 Preface to The Raven and Other Poems: "Events not to be controlled have prevented me from making ... any serious effort in what, under happier circumstances, would have been the field of my choice." 55

Later, while patrolling the dull but safe terrain of secondary sources, Dpauses outside the manuscript room. Athena is in there, privately preserved in that time-capsule that is so unlike the local Athenaeum she may have known, the public reading room that Athena would perhaps prefer. Dimagines her reclining on her side on the dusty shelves, her chin propped on one hand, her brown eyes searching the dimly-lit aisles. Athena drums her fingers against the oak, impatient to be put to some good use. She who believed that "Audience is all" now has no audience at all. But D- cannot escape that tell-tale rhythm described by Poe's narrator, that "low, dull, quick sound-much such a sound as a watch makes when enveloped in cotton."56 Ticking across decades, legally safe and sound, but unavailable for use, the heart of Athena Rhetoric beats on.

- The End -

II

\section{REFLECTIONS}

As the fictitious tale of biographer D- suggests, the ability of some writers to use previously unpublished copyrighted sources has been limited in the last half of the 1980s. Restrictive rulings have been made by the United States Supreme Court and the Court of Appeals for the Second Circuit, which is especially influential because it governs New York, where much of American book and magazine publishing occurs. Traditionally, U.S. law has attempted to strike a delicate balance, weighing an individual author's right to own his or

55. Edgar Allan Poe, Preface to The Raven and Other Poems, in Davidson, ed, Selected Writings at 452 (cited in note 1).

56. Edgar Allan Poe, The Tell-Tale Heart, in Davidson, ed, Selected Writings at 198 (cited in note 1) (emphasis added). 
her creative expression embodied in written texts against the first amendment right to free speech, the public's right to know, and society's desire to benefit from and build on what is in those texts.

That balance has been disturbed by the Harper $\mathcal{E}$ Row, Salinger, and New Era $I$ rulings, which have emphasized an author's property rights in unpublished works over interests of other authors (such as biographers and historians) and, ultimately, over the interests of the reading public. A chief rationale for this position seems to be that the original authors or their heirs should have the opportunity to publish the works first (or not to publish them at all), and that the commercial value of these unpublished works should not be reduced by others' use of them.

The debate over fair use raised by these cases, especially regarding unpublished works that might otherwise be unavailable to society, has broad significance. "This trend restricting the use of unpublished works must be examined carefully," observed Senator Patrick Leahy, "because it implicates significant competing interests." 57 The fair use debate marks zones of current renegotiations: between private and public spheres, between private and communal property, and between a Romantic or Platonic view of the author/originator and a contrasting view of authorship as socially situated. The recent judicial and legislative attempts to alter the delicate balance in these relationships may indicate that prevailing views about authorship and ownership of artistic and intellectual property are changing.

However, such theoretical and philosophical issues, although important, cannot be the only concern of authors and publishers who must make practical decisions about what research can and cannot be done, and what books can and cannot be written and read. Many concerned groups-the Authors Guild, the PEN American Center, the Organization of American Historians, the Modern Language Association, and others-requested the Supreme Court to rehear the Salinger and New Era I cases, but the court refused. Thus, the rulings restricting the use of unpublished materials remain in effect.

These recent opinions have provided little practical guidance for writers, who are apt to feel confusion and fear when they try to apply fair use decisions to their own practices. Those affected include not only the scholars such as the fictitious " $D$-_," but also many others, such as newspaper and magazine writers, historians, biographers, nonfiction writers, literary critics, graduate students, and other researchers.

At publishing houses, manuscripts are being revised, with difficulty and not without cost, to eliminate quotation from unpublished sources. Helen Stephenson, executive director of the Authors Guild, the major professional organization representing the interests of more than six thousand authors, emphasized the impact of the recent cases on books: "At the major

57. 136 Cong Rec 3550 (March 29, 1990)(statement of Sen. Patrick Leahy in support of S 2370). 
publishing houses, there is zero quotation from unpublished work; it's considered too risky by publishers' attorneys." 58

For example, excerpts from unpublished letters that John Connally had written to Lyndon Johnson (kept in the L. B. J. library) were reportedly removed from James Reston's biography of Connally. ${ }^{59}$ To Reston, finding the letters had seemed a "research coup," but they turned out to be too risky to use. "Good research was a form of entrapment," Reston concluded in a letter to Arthur Schlesinger, Jr. ${ }^{60}$ Schlesinger himself was dissatisfied by the recent court rulings. "If the law were this way when I wrote the three volumes of The Age of Roosevelt," he said, "I might be two volumes short."61 Writing in The Wall Street Journal, Schlesinger argued that the New Era I decision "strikes a blow against the whole historical enterprise."'62

The restrictions placed on direct quotations have affected authors' abilities to use original research to make a vivid point. While researching his book on school desegregation, On Common Ground, J. Anthony Lukas had traveled through Georgia swamps to uncover a Boston family's roots in slavery. In an attic, he discovered a slave owner's letter about a gift for his nephew. The slave owner wrote, "I am sorry that circumstances are such that I cannot give him a Negro, but I must do the next best thing left, that is give him a mule."63 A mere paraphrase of the facts might have diminished the impact of this statement, but after New Era I, Lukas observed, he might have had to leave that telling line out. ${ }^{64}$ Quotation of language from primary sources provides readers with direct "evidence" that allows them to see the basis for a biographer's or historian's interpretations. "The most primary source of all," according to the late Barbara Tuchman, author of The Zimmermann Telegram, The Guns of August, and A Distant Mirror, "is unpublished material . . . There is an immediacy and intimacy about these [materials] that reveals character and makes circumstances come alive." 65

Furthermore, the language of the times about which one writes is often important to a biography. "The language itself is a character," observes Paul Mariani, a biographer of poets William Carlos Williams and John Berryman. "If you're writing the biography of a woman in the nineteenth century, say, a New England woman, from Lowell, Massachusetts, working in the mills, part of what's going to matter is the specific language, even the misspellings, and her perception at that moment. Even the words that have dropped out of the

58. Telephone interview with Helen Stephenson, July 17, 1991.

59. David A. Kaplan, The End of History?, Newsweek 80 (Dec 25, 1989).

60. Letter from James Reston, Jr., to Arthur M. Schlesinger, Jr., quoted in PEN American Center and the Authors Guild, Inc.'s Brief as Amici Curiae, in Support of Petition for Certiorari, Henry Holt E' Co., Inic. $v$ New Era Publications, ApS., 493 US 1094 (No 89-869).

61. Quoted in Kaplan, Newsweek at 80 (cited in note 59).

62. Arthur M. Schlesinger, The Judges of History Rule, Wall St J Al6 (Oct 26, 1989).

63. J. Anthony Lukas, New Era Ruling Hobbles Scholars as Well as Journalists, Authors Guild Bulletin 25 (Summer/Fall 1990).

64. Id.

65. Barbara Tuchman, In Search of History, in Barbara Tuchman, Practicing History 19 (Ballantine, 1981). 
vocabulary. I think we have to at least address the language, which is itself setting up land mines and revelations." 66

The controversy over fair use of unpublished works is being debated in political, professional, and legal arenas. Following an outcry from historians, biographers, journalists, book and magazine publishers, and others, legislation was introduced in Congress in 1990. The bills introduced by Representative Robert Kastenmeier and Senator Paul Simon proposed to amend copyright law to clarify that fair use extends to unpublished as well as published works. ${ }^{67}$ According to Representative Kastenmeier, the legislation aimed "to clarify that, while the unpublished nature of a work is certainly relevant to the fair use analysis, it should not alone be determinative." 68

The bills received a show of support, including supportive Congressional testimony from some of the judges involved in the recent decisions about fair use of unpublished works, such as district court judge Pierre Leval and the chief judge of the Court of Appeals for the Second Circuit, James L. Oakes. ${ }^{69}$ However, the legislation died in committee. Apparently representatives of the computer software industry had objected to the new law, fearing that it might reduce the protection for unpublished computer source code. A Wall Street Journal article described the dilemma: "A 'snippet' may be 'fair use' of unpublished material to an author, but a snippet taken from an unpublished software program under fair-use doctrine could be enough to 'decompile' the entire program."70 Bruce Lehman, counsel for the Software Publishers Association, said, "They are talking about our crown jewels." 71

In early 1991, the Authors Guild established a Committee to Preserve Fair Use to work to eliminate the presumption against using unpublished material. According to Committee Chair J. Anthony Lukas, the presumption "threatens truly independent biography."72 Following discussions with representatives of various concerned groups, a new version of an amendment to the Copyright Act fair use section was introduced in the House by Representative

66. Paul Mariani's remarks were made in a general interview on his approach to biography, not specifically in reference to the current legal situation. See Gail Porter Mandell, Life into Art: Conversations with Seven Contemporary Biographers 36 (U Arkansas Press, 1991).

67. HR 4263 and S 2370, 101 st Cong, 2d Sess 54 (1990).

68. Joint Hearing on HR 4263 and S 2370 before the House Committee on the Judiciary, Subcommittee on Courts, Intellectual Property, and the Administration of Justice and the Senate Committee on the Judiciary, Subcommittee on Patents, Copyrights, and Trademarks (July 11, 1990)(opening remarks of Rep. Robert W. Kastenmeier).

69. Id (statements of Pierre N. Leval, U.S. District Judge, Southern District of New York, and James L. Oakes, Chief Judge, U.S. Court of Appeals, Second Circuit). However, for various reasons, these bills were not supported by the testimony of another judge at these hearings, Circuit Judge Roger J. Miner of the Second Circuit. Judge Miner suggested instead that fair use should apply to "published and publicly disseminated materials," with "publicly disseminated" meaning "any letters sent without a requirement of confidentiality and any documents, including letters, that have been in existence for a certain period of years without having been copyrighted." Id at 3-4 (statement of Roger J. Miner, Circuit Judge, U.S. Court of Appeals, Second Circuit).

70. James M. Perry, What Publishers Call Quoting, Computer Firms Call Piracy as Industries Face Off in Capitol Hill, Wall St J A24 (April 23, 1991).

71. Id.

72. Other People's Words: Fair Use or Fair Game?, NY Times E7 (Feb 24, 1991). See also Roger Cohen, Writers Mobilizing Against Restrictions on Using Quotations, NY Times C11 (Feb 20, 1991). 
William J. Hughes and in the Senate by Senator Simon. Like the previous 1990 bill, the 1991 legislation attempted to clarify that unpublished work is eligible for fair use, but with some qualification. ${ }^{73}$ The Senate approved this bill in September 1991.74 In the House of Representatives, additional testimony was heard in 1991 by the Subcommittee on Intellectual Property and Judicial Administration. ${ }^{75}$ Subsequent discussion apparently revealed some concern in this House subcommittee about language. Representative Hughes later introduced a new bill regarding fair use of unpublished material in the House (HR 4412) in March of $1992 .{ }^{76}$

Meanwhile, in the courts, two recent decisions in the Second Circuit have favored the user of unpublished material. A 1991 district court decision applied the four-factor analysis to a charge by the Arica Institute that psychology professor Helen Palmer unlawfully used material that was largely unpublished. ${ }^{77}$ Although the second factor (nature of the use) weighed against the defendant, the other three factors weighed in her favor, and Palmer's use was judged to be a fair use. ${ }^{78}$

73. In the 102d Congress, Senator Simon, with Senator Leahy, proposed the following addition to section 107 of the Copyright Act, concerning fair use: "The fact that a work is unpublished is an important element which tends to weigh against a finding of fair use, but shall not diminish the importance traditionally accorded to any other consideration under this section, and shall not bar a finding of fair use if such a finding is made upon full consideration of all of the above factors." $S$ 1035, 102d Cong, 1st Sess (May 9, 1991). The previous bill had simply stated that both published and unpublished works could be eligible for fair use.

74. Perhaps because the wording of this new version was arrived at through compromise among the interested parties (including representatives of authors, publishers, and the computer software industry) before it was introduced, there was apparently little controversy in the Senate. S 1035 was polled out of the Subcommittee of Patents, Copyrights and Trademarks (May 17, 1991), was reported favorably out of the Senate Judiciary Committee (June 13, 1991), and passed by the full Senate in September 1991. The legislative history is summarized in "Fair Use of Unpublished Works," S Rep No 102-141, 102d Cong, 2d Sess (July 8, 1991).

In the House of Representatives, Title I-Fair Use of HR 2372, introduced by Representative William J Hughes with Representative Moorehead, was identical to the Senate version except for the last sentence, which read, "if such a finding is made upon full consideration of all the factors set forth in paragraphs (1)-(4)." HR 2372, 102d Cong, lst Sess (May 9, 1991). This bill did not advance beyond the subcommittee; however, another version was introduced in the House in March of 1992, as discussed in text that follows above and in note 76.

75. The House Subcommittee on Intellectual Property and Judicial Administration held two hearings on HR 2372 (on May 30 and June 6, 1991) at which some witnesses expressed support (for example: Floyd Abrams, counsel for the Authors Guild; Mark Morril, general counsel to Simon \& Schuster; Kati Marton, biographer; Kenneth Vittor of the Magazine Publishers of America; and William Neukom of the Software Publishers Association). Others expressed some reservations about whether it was really needed (for example: Ralph Oman, Register of Copyrights; Scott Turow, author and lawyer; and Shira Perlmutter, law professor). See Compromise Fair Use Copyright Bill Suits Publishing and Computer Interests, 42 Patent, Trademark \& Copyright J (BNA) 147.48 (June 6, 1991), and Witnesses Express Doubt on Need For Amending Fair Use Provision, 42 Patent, Trademark \& Copyright $\mathrm{J}$ (BNA) 162-65 (June 13, 1991).

76. The text of HR 4412, introduced March 5, 1992, amends section 107 of title 17 to read as follows: "The fact that a work is unpublished shall not itself bar a finding of fair use if such finding is made upon consideration of all the factors set forth in paragraphs (1) through (4)." The House Subcommittee on Intellectual Property later changed the end of the sentence to read "upon consideration of all the above factors" and then approved and sent the bill to the House Judiciary Committee, where it was awaiting mark-up at the time this article was completed.

77. Arica Institute, Inc. $v$ Helen Palmer and Harper E Row Publishers, Inc., 761 F Supp 1056 (SDNY 1991).

78. Id at 1058 . 
Another relevant ruling was the previously mentioned Wright $v$. Warner Books, in which the district court's 1990 ruling in favor of biographer Margaret Walker was affirmed by the Second Circuit late in 1991. The appeals court once again held that the second factor (the nature of the use, which again involved use of materials that were unpublished) favored the plaintiff, but the other three factors favored the biographer, who prevailed in the matter. The outcome of this case lends some hope for the prospects of biography, as does the appellate court's explicit statement that "Neither Salinger, Harper E' Row, nor any other case . . . erected a per se rule regarding unpublished works."79

Less encouraging, however, was the appellate court's overall view of factor two, which disagreed with the district court's analysis and continued to emphasize protection of unpublished materials: "unpublished works are the favorite sons of factor two." 80 The unpublished material that Walker used in her biography was in this case permitted, but a key reason for permitting it was that the amount was very small—only "seven protected segments"81 (closely paraphrased or quoted), which the court of appeals described as "marginal amounts" and "sparing use," and which made up only "a slight fraction of the biography-at most, two pages of a 428-page book." 82 A ruling based on such limited use might not provide sufficient help for many works of biography, history, and criticism. Nor did the discussion in Wright provide much new guidance for authors and publishers about how to make some of the crucial distinctions, such as separating fact and idea from expression. In fact, Wright included yet another vaguely indicated, protected category: that of "borderline expression." 83 In sum, in reporting reactions to the Wright decision, The New York Times stated that "[f]ree speech advocates said the ruling was a small legal victory in a larger publishing war that they were nonetheless losing." 84

III

\section{RECOMMENDATIONS}

What should be done about this situation? First, let us consider the more immediate possibilities and then a suggestion for long-range action.

79. Wright, 953 F2d at 740.

80. Id at 737. Perhaps authors and publishers will derive some hope from the concurring opinion in Wright by Circuit Judge Van Graafeiland, which states: "In sum, I believe that my colleagues place too much emphasis on the unpublished nature of Wright's words in discussing factor (2) of 17 U.S.C $\$ 107 . "$ Id at 743. A similar concern was expressed by Floyd Abrams, who has been involved with this issue in various ways (for example, as one of the attorneys for The Nation in Harper $E$ Row; as counsel to Random House in its attempt to obtain a writ of certiorari from the Supreme Court in the Salinger case; and recently as legal advisor to the Authors Guild on matters related to the fair use of unpublished materials). Abrams reportedly told The New York Times that the Wright ruling was "another regrettable example of the Court of Appeals overemphasizing the unpublished nature of letters." Ronald Sullivan, Court Relaxes Curb On Biographers' Use of Unpublished Data, NY Times C13 (Nov 28, 1991).

81. Wright, 953 F2d at 740 .

82. Id at 739 .

83. Id at 736 .

84. Sullivan, NY Times at C13 (cited in note 80). 
1. Help researchers and writers to understand the status quo and to reduce some of the risk and cost.

Major works of biography and history can be enormously expensive and time-consuming, even without the threat of legal difficulty. The added burdens of huge legal expenses and years spent fending off lawsuits can affect what is and is not written. Without help, writers may opt for projects that seem less confusing, less costly, and less risky. Controversial projects that could produce important knowledge might be ignored or abandoned. Furthermore, books may be written cautiously, leaving out potentially risky material, which ultimately undermines the advancement of knowledge.

To help writers with such difficulties during a transitional time, perhaps some copyright lawyers would be willing to provide pro bono assistance, as Second Circuit Judge Jon Newman has suggested. ${ }^{85}$ Publishers could offer greater protection to an author by increasing the insurance coverage they extend to authors and by substantially lowering authors' deductibles.

Also, continuing education for authors could be helpful. Professional organizations might assist their members in understanding copyright by providing instructional workshops, symposia, publications, and access to inexpensive legal advice. This guidance is especially important in early stages of research and drafting, before authors have a contract with a publisher.

Librarians and curators could increase efforts to collect and supply information on matters such as names and addresses of likely copyright holders. They might also expand the practice some repositories have of asking donors to transfer copyrights to the institution or the public domain. ${ }^{86}$ While the J. D. Salingers of this world may not agree to this, others will. In so doing, they may stimulate future research in their papers, a result that is desirable to donors who hope to have their papers, or those of their ancestors, put to use.

On the other hand, if a copyright holder has strong feelings about terms or conditions for quotations from papers, librarians and curators might try to clarify such terms and make them known to researchers who consult the papers. Having accessible information about the status of unpublished material, says Peter Kurth, author of Anastasia: The Riddle of Anna Anderson and American Cassandra: The Life of Dorothy Thompson, might "at least eliminate the surprise factor" in that an author could find out if the conditions are likely to be acceptable or not before getting deeply involved in a project. ${ }^{87}$

85. Jon O. Newman, Not the End of History: The Second Circuit Struggles with Fair Use, $37 \mathrm{~J}$ Copyright Society of USA $12,17-18$ (1989).

86. Philip C. Brooks notes that "one of the strongest factors protecting the research user is the frequent practice of archival agencies to persuade the donors to transfer their rights to the repository or to the public." Research in Archives 71 (U Chicago Press, 1969). For example, the Wisconsin State Historical Society asks a living author who donates or sells papers to transfer copyright upon the death of the author or the author's heirs. See Marcia Biederman, Should You Allow Your Manuscript to be Archived?, Authors Guild Bulletin 22 (Winter 1991).

87. Telephone interview with Peter Kurth, July 24, 1991. 


\section{Urge publishers to take chances.}

Judge Jon Newman has advocated that publishers occasionally "take a strong stand in defense of a biographer's proposed use of quotations from an unpublished writing to convey factual material fairly and accurately, and accept the costs of litigation, and even the risk of an unfavorable outcome." 88 If publishers will take such risks, then legal claims, and the fear of them, might diminish, since those whose unpublished works are used in modest amounts might decide a lawsuit is not worth pursuing. In the event that a lawsuit is filed, academic and professional organizations can support the defendants (authors and their publishers) by continuing the practice of filing "friend of the court" briefs. ${ }^{89}$

Publishers can also increase preventive measures. For instance, they can offer legal advice to authors under contract early in the process of research and writing, rather than waiting to read a full manuscript. Authors' methods of research, documentation, and record-keeping are important in these matters, and errors and omissions in research cannot always be corrected in the end.

3. Request guidance from the courts.

As a non-lawyer, I admittedly arrive at this point with a disadvantage. However, as a concerned writer who has studied a number of court opinions on this matter, I feel that the courts' illustrations of how to apply relevant principles to practice in these cases are not always enlightening. For example, it is difficult to understand how the courts determine when a paraphrase is acceptable and when it is too close to the original. Also, decisions about whether a biographer has used the "heart" of another's work do not always provide a full explanation of reasons. ${ }^{90}$

Increasing this uncertainty is the fact that courts have not given clear signals about how they will continue to treat fair use of unpublished materials, as evidenced by a number of recent reversals. ${ }^{91}$ Nimmer on Copyright states that

88. Newman, $37 \mathrm{~J}$ Copyright Society of USA at 17 (cited in note 85).

89. For example, in the recent Wright case, amici curiae for biographer Walker and Warner Books were the Association of American Publishers; the PEN American Center; the Authors Guild, Inc.; the American Council of Learned Societies; the American Historical Association; the American Political Science Association; the Modern Language Association; and the Organization of American Historians.

90. Although the involved parties, lawyers, and other judges make up the principal audience for court opinions, they are not the only audience. Even legal scholars and publishers' attorneys have expressed uncertainty about how to interpret the Copyright Act and these copyright rulings.

I doubt that most people in the humanities expect or want the quantifiable certitude of, say, the late attorney Moses Malevinsky's Algebraic Formula for infringement in plays whereby an emotion (A) personified in a character (B) with certain motivations (C) could be expressed as a formulaic relationship: $A+B+C$ in two similar plays establishes infringement, "with the certainty of an engineer's T . . .." Moses Malevinsky, The Science of Playwriting (Brentano's, 1925), described in Lindey, Plagiarism and Originality at 125 (cited in note 1). But writers and publishers and their attorneys could benefit from additional guidance and examples regarding the use of unpublished material.

91. There are a number of examples of reversals and differing interpretations. In Harper $\mathfrak{G}$ Row, for instance, the district court's decision favoring the plaintiff was reversed by a divided panel of the Court of Appeals for the Second Circuit, which was in turn reversed by the Supreme Court (ruling 
the four section 107 factors for judging fair use are "protean," and that " $[w]$ hen combined with the emphasis on case-by-case adjudications in this area, the factors ... tend to degenerate into post-hoc rationales for antecedent conclusions, rather than serving as tools for analysis."92

Pierre Leval, the district court judge whose Salinger and New Era I rulings were reversed by the appeals court, has been sympathetic to the confusion felt by writers and publishers. He asserts that "[j]udges do not share a consensus on the meaning of fair use" and notes that the 1976 Copyright Act gave the courts little help on some points. ${ }^{93}$ For instance, it gave "no guidance for distinguishing between acceptable and excessive levels"94 of copyrighted materials taken by a secondary user (such as a biographer). At the same time, Leval warns that adopting "a definite standard" on the various complex issues involved in fair use determinations could "stifle intellectual activity." 95

Continued exploration of some of the muddy distinctions that operate in fair use cases might prove helpful. Some of these dichotomies, despite the fact that they have existed for some time, may in fact prove unworkable. For example, how readily can these supposed opposites be distinguished: Fact from expression? Idea from expression? Fact or idea from "borderline" expression? Words that substantiate an assertion from words that "enliven" a text? Works that are "original" from those that are "derivative"? Beyond these issues is a fundamental question: Is copyright now viewed primarily as a way to protect private property for an autonomous, "original" author or primarily as a way to stimulate intellectual activity and contribute to the public good? ${ }^{96}$

There may be hope for a change in the legal climate. If change should indeed occur, both in the theory of literary creativity that informs the court, and in the law itself, it may in fact happen, as Judge Richard Posner has noted, "in a defense of fair use." 97 The district and circuit courts have issued various, and sometimes contradictory, reactions to cases regarding fair use of

for the plaintiff). In Salinger, the district court's decision in favor of the biographer was reversed by the Second Circuit Court of Appeals. In New Era I, the district court's refusal to enjoin publication of a biography was affirmed by the court of appeals, but only because the plaintiff had waited too long to request an injunction. In Wright, the district court's decision for the biographer was affirmed by the court of appeals; at the same time, however, the appeals court disagreed with the district court's analysis of the second fair use factor (relating to the unpublished nature of the works used), which the appeals court said should favor the plaintiff rather than the defendant in this case.

92. Melville B. Nimmer \& David Nimmer, Nimmer on Copyright § 13.05[A], 13-88.17 through 1388.18 (Matthew Bender, 1991).

93. Pierre N. Leval, Toward a Fair Use Standard, 103 Harv L Rev 1105, $1106-07$ (1990).

94. Id at 1134 .

95. Id at 1135 .

96. Lloyd Weinreb notes different underlying views of copyright in Salinger and New Era $I$ in the decision of Judge Leval and the decision of the Second Circuit. Leval, he feels, views copyright as "conditional on and subservient to the public good" which would have been served by the biographers' uses of unpublished works in these two cases. In contrast, the court of appeals viewed copyright as private property to be controlled by its owner "subject to exceptional and quite limited socially justified uses." See Lloyd L. Weinreb, Fair's Fair: A Comment on the Fair Use Doctrine, 103 Harv L Rev 1137, $1158-59$ (1990).

97. Richard A. Posner, Law and Literature: A Misunderstood Relation 351 (Harvard U Press, 1988). 
unpublished works. Some judges have taken the time and trouble to write articles about the dilemma and to testify before Congress about proposed legislation. All this discussion may make the judiciary increasingly aware of the practical consequences of the recent decisions, which may in turn lead to a revised position by the courts in the future. Ralph Oman, Register of Copyrights for the U.S. Copyright Office, has noted that "[t]here is considerable evidence that the Second Circuit has moved away from some of the language in Salinger and New Era that initially caused alarm."98 He adds, however, that "the Copyright Office believes that the concerns of authors and publishers over that language is well-placed, if only because of the lack of predictability in the law." 99

4. Lobby Congress for legislative change clarifying the status of unpublished material and clarifying (and possibly relaxing) fair use guidelines.

As discussed previously, the process of amending the law began in 1990 with the introduction of bills concerning unpublished material, and it has continued on into 1992. If such legislation is not enacted, or if the courts do not ease the current restrictions on fair use of unpublished works, the prospects for biography and history are troubling.

During this transitional time, there are still questions about the proposed legislative changes. Is legislation needed at this time? Or would it tend to codify matters that should evolve through case law? Does proposed legislation simply clarify the law, or does it alter it? Is it clear enough and strong enough to help authors and publishers?100

Despite such questions, a number of people who have been closely involved with this issue for a long time feel optimistic that the difficulties of biographers and historians would be eased with passage of appropriate legislation. ${ }^{101}$ In introducing the 1991 bill, Senator Paul Simon said that this legislation would clarify the matter "that the unpublished nature of a work should not create a virtual per se bar to its use."102 Unpublished works, he said, would receive the complete analysis currently used for all copyrighted works. This bill was intended to "restore the appropriate balance between

98. Hearings on HR 4263 and S 2370 before the Subcommittee on Courts, Intellectual Property and the Administration of Justice of the House Judiciary Committee and the Subcommittee on the Constitution of the Senate Judiciary Committee, 102d Cong, 2d Sess 64 (1990) (statement of Ralph Oman, Register of Copyrights and Assistant Librarian for Copyright Services).

99. Id.

100. Mary Sarah Bilder observes that proposed bills that "continue to support an interpretation that unpublished material receive narrow fair use considerations . . . change nothing for normative biography." Bilder, 43 Stan L Rev at 355 (cited in note 23).

101. For example, Professor Leon Friedman, counsel to the PEN American Center and one of the attorneys who represented The Nation in Harper $\xi$ Row, wrote an editorial in support of $S 1035$ (since passed in the Senate). See Leon Friedman, Quoting History, 252 The Nation 759-60 (June 10, 1991). Others who have favored amending the Copyright Act in some way regarding fair use of unpublished material are cited in notes $68,69,73$, and 75 . Authors' and publishers' organizations that have been involved in this legislative action include the Authors Guild, the PEN American Center, the Magazine Publishers of America, and the Association of American Publishers.

102. Quotations from Simon in this paragraph are from "Floor Statement of the Honorable Paul Simon on Introduction of Legislation to Clarify Fair Use Doctrine under Copyright Law," May 9, 1991, United States Senate. 
copyright owners and the interests of scholarship and journalism," a balance that recent court decisions had disturbed. ${ }^{103}$

Authors Guild director Helen Stephenson has observed that passage of the 1991 proposed legislation or a version similar to it would "remind the courts of Congressional intention." 104 The fact that a work is unpublished would still be important, but it would no longer be "the trump card." According to Stephenson, such a law "would put us back where we were after Harper $\mathcal{G}$ Row but before Salinger and New Era." 105 Although the recent Wright decision went in the right direction for those favoring fair use of unpublished materials, it did not accomplish all that was desired. Legal experts consulted by the Authors Guild reportedly felt that "the Wright case was the one 'factperfect' case that they could hope to win even if a virtual per se rule against the fair use of unpublished material were to prevail."106 Given the facts of that case and the very small amount of unpublished material used, the ruling has not alleviated all concerns nor halted the move to amend the law.

If and when new legislation passes, speculation about its effects will continue for some time until more cases are decided by the courts. If this legislation clearly legitimizes some use of unpublished works, then even if it is not perfect, it will certainly be an encouraging step, especially if the courts consider not only the letter of the law but also the legislative history and intent. Furthermore, the process of legislative review has been helping to heighten the awareness of many people about what is at stake and why it matters.

In the future, more should be done in Congress to clarify (and perhaps loosen) fair use guidelines on issues concerning the quantity and type of material used, as well as the purpose of the use. Such matters have not, however, been taken up in the recently proposed legislation. As Register of Copyrights Ralph Oman has noted, the bills proposed in 1991 did not provide "guidelines that will help decide whether a particular use of unpublished material is a fair use."107

Admittedly, it is not easy to clarify such matters without destroying the flexibility that the fair use provisions supposedly offer. Asking for Congressional assistance is not to suggest that the current fair use problems are due entirely to Congress's actions in creating the 1976 Copyright Act. In fact, as Jessica Litman has pointed out, Congress devoted twenty-one years to the development of the Copyright Act, and that process involved much study, debate, compromise, and "congressional midwifery," in which legislators and their staffs attempted to help authors, publishers, and other interested parties

103. Id.

104. Telephone interview with Helen Stephenson, July 17, 1991.

105. Id.

106. Helen Stephenson, Guild Continues Fight for New Fair-Use Law, Authors Guild Bulletin 6 (Winter 1992).

107. Hearings on HR 2372 before the Subcommittee on Intellectual Property and Judicial Administration of the House Judiciary Committee, 102d Cong, 2d Sess 8 (1991) (statement of Ralph Oman, Register of Copyrights). 
to negotiate much of the language ${ }^{108}$ Ambiguity in some fair use provisions may have been intentional, Litman explains, because the parties did not actually resolve their differences-as in, for instance, the ambiguous compromise language arrived at between educational institutions and copyright owners' representatives over fair use in educational photocopying. ${ }^{109}$

Although resolving some of the ambiguities about fair use may be difficult, hopefully the passage of more than fifteen years since the 1976 Act, together with the careful analysis of relevant litigation during that period, will help in providing perspective. However, the passage of time raises another relevant issue. Some of the difficulties over fair use have been complicated by new technologies that have evolved and continue to change. In the future, Congress must address the question of whether existing copyright law can realistically continue to be used to govern not only its traditional sphere, but also the rapidly changing world of computers and digital media.

This issue has been evident in the debate over fair use of unpublished works. The computer industry did not cause the Salinger and New Era controversies, but it has clearly influenced the ensuing legislative attempts to draft laws that could meet the needs of authors and publishers without causing intellectual property problems for the computer software industry. Recent commentators have emphasized the need for continuing explorations of ways in which the legislative and judicial systems can deal with the diverse and changing needs brought by new technologies. ${ }^{110}$

\section{IV}

\section{ConClusion}

Finally, I have a more ambitious recommendation: we can reconsider the views of authorship and ownership of texts that affect research and scholarship, our legal system, and our society.

The metaphors we use often tell us something about our assumptions, and, indeed, metaphors influence our thinking in subtle ways of which we are often unaware. In this sense, the "heart" in American copyright law tells a tale about how our society regards invention and creativity. It seems natural, and harmless enough, to see organic metaphors appearing in court opinions that deal with the generation of something new. Justice Sandra Day O'Connor states in Harper $\mathcal{E}$ Row that copyright law is intended to increase the "harvest of knowledge" by "fostering the original works that provide the seed and substance of this harvest."111 Continuing in this organic vein, we have

108. Jessica D. Litman, Copynght, Compromise, and Legislative History, 72 Cornell L Rev 857, 871 (1987).

109. Id at 887-88.

110. Pamela Samuelson has noted that the characteristics of digital media "seem likely to change the face of intellectual property as we know it." Pamela Samuelson, Digital Media and the Law, 34 Communications of ACM 10, 23-28 (Oct 1991).

111. Harper \& Row, 471 US at 547 (emphasis added). 
seen that the author develops a "corpus": a physical body of texts, each of which has a "heart." In fact, texts may have other body parts as well. In the 1989 district court decision in Love $v$. Kwitney, the court determined that an author's quotations from an unpublished paper exceeded fair use, reasoning that "[i]f what the Supreme Court refused to permit in Harper E' Row was a taking of 'essentially the heart of the book,' . . . the taking here involves nearly every vital organ of the paper." 112

Such personification of the creative process and of texts traces back for centuries, but it was particularly evident during the Romantic period, which emphasized the closeness of the author or artist to nature. For example, Wordsworth's Preface to Lyrical Ballads uses a circulatory metaphor to personify poetry and prose alike: "the same human blood circulates through the veins of both."113 In current U.S. law, the life of the body of work (with its "heart") survives the termination of its author and is thereafter protected or controlled by heirs through copyright.

Contemporary use of organic metaphors to describe the writer, the writing process, and the written text underscores the continuing prevalence in America of a view of authorship that goes by various names, among them Platonic, Romantic, and expressionistic. ${ }^{14}$ These views share a basic conception of the writer as an atomistic, solitary unit inspired from within. Writing is seen as a private activity carried out through introspection, directed by an innate mechanism. The writer functions in a closed system (a garret, a library carrel, a cabin in a writer's colony) without necessarily interacting with others or with the environment.

Similarly, the blood of the author's "heart" circulates within its enclosed system. (This view contrasts with the medieval Christian concept of the

112. Love v Kwitney, 706 F Supp 1123, 1134 (SDNY 1989) (emphasis added; citation omitted).

113. William Wordsworth, Preface to Lyrical Ballads (1800), in Carlos Baker, ed, The Prelude: Selected Poems and Sonnets 11 (Holt, Rinehart and Winston, 1965).

Recall also John Locke's (1690) use of natural images to discuss property ownership in his influential theory (for example, drawing water, cultivating land, gathering acorns and apples and "other fruits of the earth"). Second Treatise of Government ch 5, § 31 and passim, in Peter Laslett, ed, John Locke: Two Treatises of Government (Cambridge U Press, revised ed 1960). Locke argues in part that people own their own bodies and own what they produce through the labor of their bodies, as long as what they remove from nature by their labor allows "enough, and as good left in common for others." Id at $\S 27$. Lockean theory has been a source for a natural law justification for recognizing authors' property rights in their creations, as discussed in, for example, Craig Joyce, William Patry, Marshall Leaffer \& Peter Jaszi, Copyright Law 15 (Matthew Bender, 2d ed 1991).

114. A Platonic view of rhetorical invention is described in Karen Burke LeFevre, Invention as a Social Act 10-32 (Southern Illinois U Press, 1987). "Expressionistic" rhetoric is critiqued by James Berlin in Rhetoric and Ideology in the Writing Class, College English 477-94 (Sept 1988). The myth of the solitary writer is questioned in studies of collaboration described by Lisa Ede \& Andrea Lunsford in Singular Texts/Plural Authors: Perspectives on Collaborative Writing (Southern Illinois U Press, 1990). The history of writing groups as a contrast to the view of author as "solo performer" is discussed in Anne Ruggles Gere, Writing Groups: History, Theory, and Implications (Southern Illinois U Press, 1987).

The evolution of "authorship," with its Western emphasis on a Romantic view as "a unique individual uniquely responsible for a unique product" is traced in Martha Woodmansee, The Genius and the Copyright: Economic and Legal Conditions of the Emergence of the "Author," 17 Eighteenth-Century Studies 425, 425-48 (1984). Peter Jaszi explores ways in which the construct of the "author" has been used in legal discourse in Toward a Theory of Copyright: The Metamorphoses of "Authorship," 1991 Duke L J 455. 
"bleeding heart," which, Lewis Hyde notes, is not confined within individual bodies but is "lifted to a greater circulation." 115 ) The atomistic writer "expresses" (presses out what is inside) a text containing an inviolable and unique entity, which, according to capitalist practice, is owned by the author and may be sold.

There has been much criticism of this atomistic concept of the writing self-too much to explore here except in passing. To sum up, it fails to take into account the social origins, influences, and consequences of invention. It abstracts writers from society, deemphasizing or ignoring their constant interactions with socially created language, forms, and norms. It overlooks the fact that social and cultural features are embedded in each individual, and that many ideas, images, and texts derive from the heritage created by others, living and dead. Furthermore, it neglects the power of social collectives that may shape, encourage, or inhibit an individual's invention and creative expression. ${ }^{116}$

Despite its shortcomings, this atomistic view continues to exert force in America, perhaps because it is fused with (and reinforced by) capitalism, individualism, and patriarchal assumptions. Not surprisingly, the Romantic view of authorship and originality has extended to the legal arena. American law enforces the concept of the autonomous author, determining what a writer owns and what material a writer may use for invention in texts. What Gregory Bateson criticized as the concept of an isolated self "bounded by skin" 117 has become, after an author's death, a self that lives on in written pages-no longer bounded by skin, but by court subpoena instead.

We have seen that organic metaphors associated with the Romantic view of authorship are present in judicial opinions about copyright law, which discuss, for instance, taking the "heart" or "vital organ" or "vividness" of an author's text and using it to "enliven" the text of another. Do these metaphors help or hurt our understanding of the issues? Why is metaphor centrally employed in such opinions? For example, courts use the "heart" metaphor instead of stating more explicitly the criteria one might use, such as that which is the most representative, interesting, original, revealing, or significant part of the "original" author's expression. No doubt judges choose metaphor because its inexactness allows them a welcome latitude and flexibility. However, this strength of metaphor is also its weakness, since flexibility can translate into confusion when others try to extract general principles from a particular case.

Perhaps personification of the text to this extent is clouding our perceptions. The organic metaphors in legal analysis may unhelpfully direct attention to what an originator has rather than to what an audience gets. Despite what the opinions say explicitly, perhaps courts are in effect not really protecting the "heart" or "expressive content" that one supposedly

115. Lewis Hyde, The Gift: Imagination and the Erotic Life of Property 139 (Vintage, 1979).

116. LeFevre, Invention as a Social Act at 22-32 (cited in note 114).

117. Gregory Bateson, Steps to an Ecology of Mind 485 (Ballantine, 1972). 
possesses, but rather, one's ability to disseminate or sell that substance to a potential audience.

Furthermore, such personification of text may elevate an inanimate object to a position of undue importance. The heart metaphor may focus attention on the isolated, enclosed object (bound between covers, with its own "heart" and circulatory system) rather than on the larger social context of which it is a part. "For books continue each other," Virginia Woolf has told us, "in spite of our habit of judging them separately." 118 In a recent book, Martha Minow observes that legal studies may find useful "intellectual challenges" in the scholarly work from many fields that has "explored the significance of relationships and challenged modes of thought that rest upon autonomous and discrete items or persons." 119

Using an organic metaphor-"seed" or "harvest" or "heart"-may even misrepresent the process of creating something new. According to Silvano Arieti's analysis in Creativity: The Magic Synthesis, creativity involves a partnership and interaction between individuals, society, and culture. ${ }^{120}$ An individual's creative expression is not comparable, for Arieti, to an acorn's growth. Whereas an acorn, given proper conditions, must become an oak and nothing else, the outcome is much less certain for the development of the creative individual. Use of a seed's growth as a metaphor for creativity may imply misleadingly that creativity develops inevitably through the extension of an individual's innate potential. It may suggest that creativity is something one has (or does not have) rather than what one does as a being that is inevitably social as well as individual.

Given these and other questions, further study of metaphors in judicial copyright opinions could contribute to resolving some current difficulties. Given their economy and flexibility, their beauty and connotative power, metaphors are often of extraordinary value to thinking and writing. We cannot do without them. At the same time, one can question whether a central metaphor in a text or in a field of discourse becomes used so automatically that its appropriateness goes unexamined. It is possible, as poet $T$. R. Hummer points out, that a given metaphorical proposition that had its beginning as "a hypothetical as if has taken on the form of a statement of fact. And then," Hummer continues, "the entire proposition may find a home in a single word that is powerfully charged with unconscious assumptions "121

Once such a metaphor is identified, one wonders what to do about it. It can be instructive simply to acknowledge metaphor (such as the cluster of

118. Virginia Woolf, $A$ Room of One's Own 84 (Harcourt, Brace \& World, 1929, 1957).

119. Martha Minow, Making All the Difference: Inclusion, Exclusion, and American Law 192 (Cornell U Press, 1990). Among the fields Minow discusses are anthropology, psychology, philosophy of science, literary theory, political science, and especially feminist theory and history. See id at ch 7, at 173-226 ("The Emergence of the Social-Relations Approach").

120. Silvano Arieti, Creativity: The Magic Synthesis 307-11 (Basic Books, 1976).

121. T. R. Hummer, Against Metaphor, in Robert Pack \& Jay Parini, eds Writers on Writing 87-88 (U Press of New England, 1991). 
organic metaphors in copyright), observing its truths and its untruths. A metaphor that is judged to be misleading might at times be counteracted, Hummer observes, by "hardheaded literal-mindedness"; but since this, too, has its dangers, he notes another alternative: "At least half the time, the only cure for a bad metaphor is a better one." 122

In the area of copyright, analyzing central metaphors (and, if necessary, searching for alternatives) can help to clarify or question underlying assumptions about authorship, originality, and intellectual property. Prevailing views of these concepts now appear to be in flux, and the laws governing them may need to change. However, we should not place all blame and responsibility for solutions on the law. The legal system is certainly not the only system that ought to be dealing with these issues. Still, it is scarcely surprising that disputes over texts and intellectual property are left to the courts, which increasingly bear the weight of so many of the difficult decisions in American society. Thus, a multifaceted issue such as fair use of unpublished texts unfortunately becomes decided almost exclusively by rules of law that emphasize economic principles of Western capitalism.

The value that copyright protects in the market economy does not come without cost to a community. When a society becomes fragmented, there is an imbalance between the individual and the social collective, between separate and corresponding lives. In America there now appears to be an overemphasis on the individual's ownership of a commodity and a decrease in the benefits of the exchange of gifts (such as ideas, texts, forms) in the wider community. In such a case, as Lewis Hyde notes in his analysis of art as gift, people are unable to receive, contribute toward, and pass along the collective treasures we refer to as culture and tradition."123

As one who has for some time studied rhetorical invention-viewed in part as the generation of ideas, information, propositions, arguments, lines of reasoning, and structures that form the subject matter of discourse-I cannot help but be concerned by certain developments in intellectual property law of which I have been made aware in recent years. Jane Gaines has noted "a tendency in American intellectual property to expand and stretch, to enlarge the domain of protectable culture and to extend the duration of the monopoly grant to owners." 124 Concerning copyright in particular, the authors of Copyright Law note that since the inception of Anglo-American copyright, "protection has been afforded to a progressively larger variety of works, for longer periods of time, against a wider range of unauthorized uses." 125 Many texts and patterns, voices and images therefore are protected by law and do not circulate as potential sources for others' invention.

122. Id at 94 .

123. Hyde, The Gift at 38-39 (cited in note 115).

124. Jane M. Gaines, Contested Culture: The Image, the Voice, and the Law 107 (U North Carolina Press, 1991). Gaines explores images from popular culture as property, discussing developments in intellectual property law in part by analyzing a number of cases, such as alleged appropriation by imitation of one's voice or one's face and figure-c"sound-alike" and "look-alike" cases.

125. Joyce, Patry, Leaffer \& Jaszi, Copyright Law at 19 (cited in note 113). 
I worry that this trend-as seen, for example, in the recent restrictions on the use of unpublished writings-will, if taken to extremes, significantly constrain creativity, rather than provide the stimulus generally expected to result from the monoply that the law grants to creators. ${ }^{126}$ Those who build on what has come before them (and who does not?) and on what is around them (at least some of which is arguably part of "their" culture) become preoccupied with self-censorship, wary of what they may or may not say, who owns what, who might be watching. Such a climate is inimical to invention, which thrives on experimentation with ideas, materials, forms, traditions, texts, and many other resources.

It may seem naive or idealistic to raise broad questions about invention, authorship, and ownership of intellectual property, concepts that seem so deeply entrenched. Yet these concepts have changed drastically in the past, and there is no reason why they cannot change again. One hundred years ago, an editorial in the London journal of the Society of Authors complained that "those who talk of literary property as if it was a real thing, like turnips, are regarded as madmen." 127 In the 1990s, text has indeed become this "real thing, like turnips," and those who wish to reconsider the nature of the author and the text should not mind similar accusations.

The courts should rehear the case of the autonomous author. Indeed, "discovery" has been proceeding for some time in a number of fields of study. Evidence can be introduced from various cultures and from theorists, past and present, who offer alternative ways to think about invention, authorship, and intellectual property. Among these are Africans, Native Americans, Marxists, poststructural and reader-oriented theorists, social constructionists, anthropologists, and feminists-to name but a few.

A book of poetry entitled Selves by Philip Booth includes "Words Made From Letters," which describes the knowledge that the poem's narrator-the individual "self" - has gained through extended correspondence with others. The narrator holds a letter received from an absent author and says: "I hear you/as I read you, fingertip to fingertip against/the same gray page." 128 I am left to ask: How can writers, selves with lives that are both separate and corresponding, converse more easily across that page?

126. The Constitution provides that "Congress shall have the Power ... to promote the Progress of Science and useful Arts, by securing for limited Times to Authors and Inventors the exclusive Right to their respective Writings and Discoveries." US Const, Art I, \& 8.

127. Walter Besant, Thou Shalt Not Throw Stones, reprinted in Richard Findlater, ed, Author! Author! 92 (Faber \& Faber, 1984).

128. Philip Booth, Words Made from Letters, in Philip Booth, Selves 54 (Viking, 1990). 
